\title{
TTR
}

Traduction, terminologie, re?daction

\section{Jean Darbelnet (1904-1990)}

\section{Geneviève Mareschal}

Volume 3, numéro 1, 1er semestre 1990

L'agora de la traduction

URI : https://id.erudit.org/iderudit/037055ar

DOI : https://doi.org/10.7202/037055ar

Aller au sommaire du numéro

Éditeur(s)

Association canadienne de traductologie

ISSN

0835-8443 (imprimé)

1708-2188 (numérique)

Découvrir la revue

Citer cet article

Mareschal, G. (1990). Jean Darbelnet (1904-1990). TTR, 3(1), 13-13.

https://doi.org/10.7202/037055ar

Tous droits réservés @ TTR: traduction, terminologie, rédaction — Les auteurs, d'utilisation que vous pouvez consulter en ligne.

https://apropos.erudit.org/fr/usagers/politique-dutilisation/ 


\section{Jean Darbelnet}

\section{4-1990}

Le monde de la traduction est en deuil. Le 12 mars dernier, en effet, nous apprenions avec tristesse et regret que Jean Darbelnet n'était plus.

Professeur émérite de l'Université Laval, Docteur honoris causa de l'Université d'Ottawa, Jean Darbelnet a consacré sa vie à l'étude comparée du français et de l'anglais. Auteur de plusieurs ouvrages et de très nombreux articles dans ce domaine, co-auteur de la célèbre Stylistique comparée du français et de l'anglais, il a véritablement jeté les bases d'un champ de recherches et de réflexions théoriques et pratiques utiles non seulement à tous les traducteurs, mais à tous ceux que le passage d'une langue à l'autre intéresse.

Défenseur acharné d'une langue française de qualité, il a mis son savoir et sa compétence à la disposition de la collectivité québécoise dans sa lutte quotidienne pour l'amélioration de sa langue. Par ses chroniques, ses écrits, ses communications, il a contribué sans relâche à l'éducation langagière de ses concitoyens d'adoption. Son dernier ouvrage, Dictionnaire des particularités de l'usage, apporte un témoignage convaincant de son érudition, de son jugement et de son respect de la langue et d'autrui. 